\title{
Conspiracy, God's Plan and National Emergency \\ Kachin Popular Analyses of the Ceasefire Era and its Resource Grabs
}

\section{Laur Kiik}

\section{Introduction}

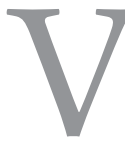

isiting Yangon in 2014, I noticed some well-meaning locals refer to the dragging Kachin military-political impasse by stating: 'The Kachins are being too stubborn, too emotional now'. Other observers find such talk belittling. They respond by emphasising how 'The Kachins merely demand that Myanmar begin genuine political dialogue on federalism' and 'are thus correct in refusing simply to sign a new ceasefire. This oscillation between explaining the Kachin impasse either through collective emotional trauma or through formal political discourse misses what Mandy Sadan identified in her monograph on Kachin histories as 'social worlds beyond.' ${ }^{1}$ As this chapter tries to show, these are diverse, contradictory, and ambitious social worlds that people live within. They cannot be encapsulated by inaccurate and homogenising expressions like 'the Kachins', 'are emotional', or 'want federalism'. It is the argument of this chapter that the way people in these worlds understand their ceasefire experiences to express ethno-national emergency, divine predestination, and ethnocidal conspiracy influences directly their contemporary responses to ceasefire politics.

1. Mandy Sadan, Being and Becoming Kachin: Histories Beyond the State in the Borderworlds of Burma (Oxford: The British Academy and Oxford University Press, 2013), 455-60. 


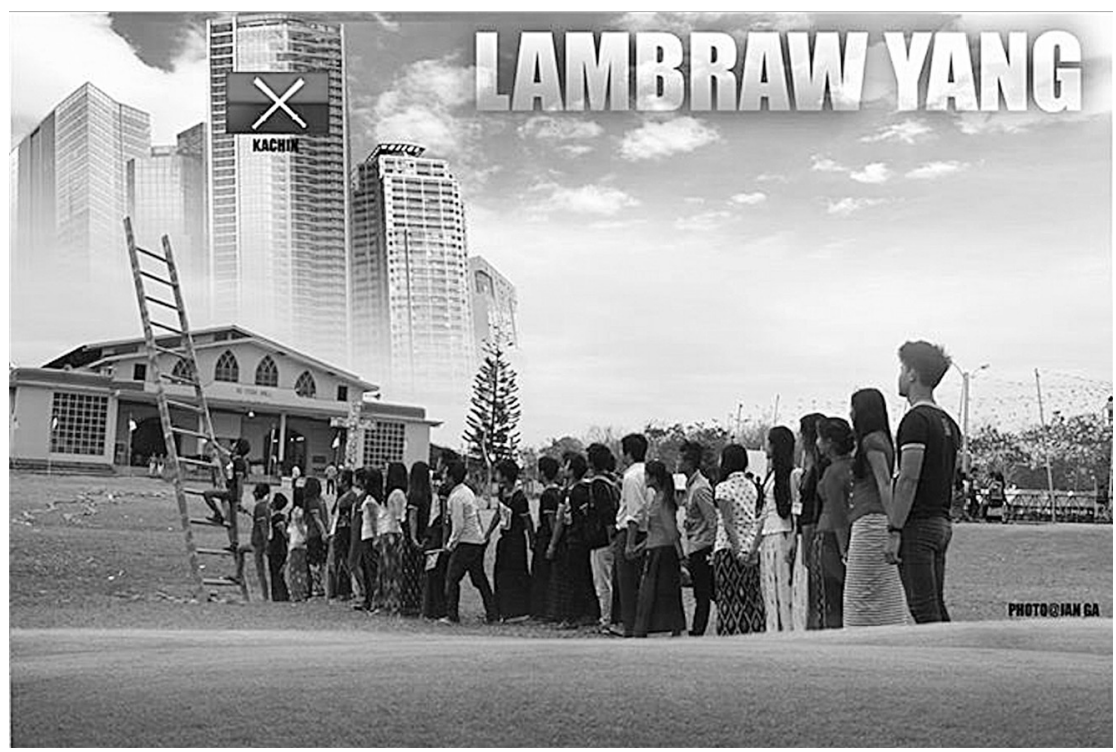

Figure 8.1: Many Kachin patriots are working for a future Kachin national modernity - a homeland yet-to-be (photo Hpauyam Awng Di).

Many chapters in this volume refer to a hardening of Kachin nationalist rhetoric in recent years, in particular the chapters by Mahkaw Hkun Sa, Nhkum Bu Lu, Jenny Hedström, and Hkanhpa Tu Sadan. These chapters often refer to the sense of fear and threat that runs through popular discourses on why the Kachin should support a return to conflict following years of ceasefire. They also reflect widespread concerns about what a peace might bring should a ceasefire be restored too easily. Many contributors also discuss the role that experiences of large-scale land and natural resource grabbing have played in sharpening the resistance. Later in this volume Reshmi Banerjee mirrors many of these concerns in her discussion of similar conflict settings in north-east India, and we see this also in the chapters by Meehan and Gravers describing conflicts elsewhere in Burma. This perception of threat in ethnic Kachin society in turn has contributed to a situation in which most Kachins have supported the KIO's military resistance to the Myanmar Army's provocations and, just as importantly, it has made an easy return to ceasefire more difficult because of a lack of popular support in Kachin society for doing so. 
This chapter, therefore, tries to take seriously and to discuss in critical terms how large parts of Kachin society understand the ceasefire era and its 2011 collapse. It focuses particularly on popular understandings of the large-scale resource grabs which defined much of that era. However, my approach is different to that which explains the current Kachin armed conflict primarily as two armies battling each other over rich natural resources; neither do I seek to reduce Kachin popular theories of nationhood and homeland simply to 'resource nationalism'. Such reductionist approaches continue historical misrepresentations of Kachin society, making it appear devoid of political ideologies and led by an 'inauthentic insurgency.2 Karin Dean has called out similar state-centric discourses for belittling the popular legitimacy of the KIO. ${ }^{3}$ What this chapter explores, then, are the politicised social worlds beyond KIOand-State relations and beyond these persisting misrepresentations.

The chapter proceeds by discussing first some currently prevailing forms of Kachin ethno-nationalist 'theory'. The term 'theory' is meant to signal this chapter's cultural-anthropological approach of foregrounding evolving native terms, through which large parts of a society understand the world in the broadest, 'cosmological' sense. Expanding upon Sadan's historiography of how Kachin ethno-nationalism evolved, I extend the treatment of Kachin political theories to the 'cosmological', mainly by showing how the 'political' and the 'religious' (Christian) cannot be completely disentangled. After briefly describing some collective Kachin experiences of the ceasefire and concurrent resource grabs, the chapter then focuses on those experiences and processes as an object of what I call 'popularised analyses'. The term 'analyses' expresses this chapter's goal to take seriously the thought projects that people engage in actively, both individually and collectively, to make sense of the world and its developments. These analyses are co-produced and circulated by Kachin-identifying national leaders, activists, educators, religious figures, and crucially, by the whole society at large. Their conclusion deduces that, even though there have been 17 years of ceasefire, Kachin society is facing threatening conspiracies and a national emergency. The chapter concludes by showing how these native theorisations and popu-

2. See Sadan's critique of colonial era discourses and of Robert Taylor's misrepresentations of ethno-national insurgencies in Ibid., 65-74, 260-270, 319-21, 466.

3. Karin Dean, 'Peace Means Surrender in Myanmar', Asia Times (24 January 2013). 
lar analyses presently guide many people in Kachin society to commit to resistance and the ethno-patriotic project of co-building a 'land yetto-be', instead of engaging in a ceasefire based on compromise. Much of this argument can be extended to other minoritised ethnic nations in Myanmar and beyond.

The following discussions draw primarily from periods of ethnographic field research in the Kachin region from 2010 to $2015 .^{4}$ To protect the security of my Kachin collaborators, who come from a relatively wide range of social backgrounds, I do not give their names here. In terms of my other ethical commitments, I work by assuming that creating more public understanding will ultimately help to bring better solutions, but that this might include revealing issues that some of my informants and friends would prefer to remain beyond open public debate. ${ }^{5}$ Thus, I avoid the censoring of internal conflict and other forms of 'ethnographic refusal', which sometimes characterises studies about social resistance. ${ }^{6}$ While exploring the nationalist theories and popular analyses, I will throughout this chapter step into a kind of open critical dialogue with them, suggesting ways in which they are contradicted or complicated by other social realities. This is to draw a fuller, fairer, and more balanced picture of the complex social dynamics in this region. However, the primary point to understand about the given popular

4. The fieldwork sessions were made possible financially by an Estonian Institute of Humanities (EHI) Research Grant (with Karin Dean and Mart Viirand) in 2010; by a Sasakawa Young Leaders Fellowship Fund (SYLFF) Grant in 2011; and as part of the project Integration in Southeast Asia: Trajectories of Inclusion, Dynamics of Exclusion (SEATIDE), funded by the European Commission's 7th Framework Programme, in 2013-2014 and 2015. Support has also been provided by a Fulbright Grant, by Columbia University and its Department of Anthropology. Karin Dean, my colleague at Tallinn University, first introduced me to the Kachin region and has been steadfast in her support of my efforts ever since. Also, I thank Mandy Sadan for her committed editorial work which has been extremely helpful. Finally, I owe enormous gratitude to my Kachin friends and colleagues whose support and knowledge have made my study altogether possible.

5. For a reflection on ethical dilemmas faced by foreign researchers who study Myanmar minority ethnic nations, while their native colleagues are engaged in nationalist projects, see Patrick McCormick, 'Ethnic Histories: Reflections from the Field', The Journal of Burma Studies 18, no. 1 (2014).

6. Sherry Ortner, 'Resistance and the Problem of Ethnographic Refusal', Comparative Studies in Society and History 37, no. 1 (1995). 
interpretations is not whether they match neatly a reality on the ground, but that they exist in the form that they do, that they are widely circulated, and that they evoke and express a tangible sense of threat.

\section{Kachin nationalist theory and its discontents}

This chapter shall focus on the dominant forms of popular analysis that circulate most widely and publicly inside Kachin society. In order to explore how ceasefire era developments have been understood in contemporary Kachin society, I will begin by outlining some of the nationalist-theoretical frameworks of a dominant Kachin political discourse. I will do this by discussing three core terms. These are Kachin versions of three globally circulating, basic ontological categories that are very much in the tradition of $19^{\text {th }}$ century European, modern nationalisms: Wunpawng Mungdan (territory/ 'Kachin country'), Wunpawng myusha (people/ 'Kachin nation'), and Karai Kasang (divinity/ Christian 'God').?

I will highlight some very sensitive, but crucial, discontents, as they relate to Wunpawng Mungdan, Wunpawng myusha, and Karai Kasang. I do this to emphasise the core complexities, contests, and variations within Kachin society and in the current political impasse. I hope to caution against the tendency to make homogenising claims about Burma's minority ethnic nations, as if these were simple monolithic entities and not internally diverse, class-stratified, and complex societies. Not least, too often these national societies are falsely equated with prominent ethnic armed organisations, as when calling the United Wa State Army 'the Wa', the KIO as 'the Kachin', or indeed the Myanmar Army as 'the Burmans'. Simultaneously, some elite voices within the minority societies routinely exaggerate their capability to represent a heterogeneous population's experiences and perspectives. Yet, their discourses sometimes get transmitted uncritically to outside audiences. Similarly to how Campbell has articulated that there is no

7. I will hereafter write these three Jinghpaw language terms un-italicised and intermixed with English equivalents. Their disruptive presence is to establish throughout the text an intellectual register for engaging a social world and certain perspectives on their own terms, cognisant of the limitedness of all cultural translation. This choice is inspired by Ty P. Kāwika Tengan, Native Men Remade: Gender and Nation in Contemporary Hawai'i (Duke University Press, 2008). 
single 'the Karens', I emphasise here that obviously there is no unitary 'the Kachin people., ${ }^{8}$ My discussion here, too, cannot represent many Kachin social groups adequately, for instance, because I have done too little ethnographic fieldwork with rural village farmers or with Kachin populations in Shan State.

The main unit of geo-political reference for most people who identify as Kachin patriots is not 'Myanmar' or 'the state'; neither is it 'the Kachin regions of northern Burma' within which the state-official 'Kachin national race of Myanmar' resides. Instead, the main unit of patriotic geo-political analysis is 'anhte Wunpawng Mungdan' - 'Our Kachin country/Kachinland'. Even though Kachin nationalists are daily reminded of their presence inside the state of Myanmar, they do not envision anhte Wunpawng Mungdan as being simply a marginal, problematic area of this sovereign state. Rather, for them it is a historical, independently standing, self-evident, and naturally central body of affairs. This centrality reaches cosmological scale when popular analysis incorporates the ultimate agency of Karai Kasang, 'God', as will be discussed below. However, because this type of ethno-nationalist theory approaches territory in an ethnic-nation-centric framework, it stands continuously at odds with the global inter-state governance regime and the Myanmar government's theorisations of country sovereignty. ${ }^{9}$

Like in the cases of several minority ethnic nations in Myanmar, Kachin patriots take having a 'State' bearing their ethnonym very seriously. People usually equate Wunpawng Mungdan with the geographic limits of the Myanmar state's official administrative entity, the Kachin State. Even if not a full-blown independent country (yet), the Kachin State's internationally recognised official existence, its clearly delineated boundaries, and its name designating this territory as being fundamentally 'Kachin' - on paper, in law, on maps - are seen as sources of legitimacy and existential security enabling the pursuit of a Kachin ethno-national mandate. The creation of Kachin State as part of Burma's

8. Stephen Campbell, 'Articulating Grievance in Southeast Myanmar', in Civil Wars in South Asia: State, Sovereignty, Development, ed. Aparna Sundar and Nandini Sundar (New Delhi: Sage India, 2014).

9. Karin Dean, 'Spaces, Territorialities and Ethnography on the Thai-, Sino- and Indo-Myanmar Boundaries', in Ashgate Research Companion to Border Studies, ed. Doris Wastl-Walter (Ashgate Publishing, 2011). 
independence process is considered a historical victory of significance and the territory is seen as the womb of all 'our' possible futures. Fears of losing this state-official basis of Wunpawng Mungdan have been heightened during the ceasefire period because of a sense of threat from an aggressive Myanmar sovereignty. Such fears cause Kachin patriots great emotional stress and heartache, as we will explore below.

Yet the way Kachin nationalists perceive their nation as 'owning' this territory, just like Myanmar's other so-called 'national races' are said to 'own' their respective States, contradicts with the on-the-ground reality of a deeply multi-ethnic demographic, as also discussed by Reshmi Banerjee in this volume in relation to the situation in north-east India. Most Kachin political propaganda, media, and public discourse talks of the territory in essentialist terms as 'anhte Wunpawng Mungdan', 'our Kachin land/country'. Nevertheless, rich and intermixed ethno-linguistic patchworks have always characterised the mainland Southeast Asian 'Zomian' ${ }^{10}$ mountain-scape, of which the Kachin region is a part. It is estimated that about half of Kachin State's population is ethnically nonKachin, including Shans, Burmans, Gurkhas, Indians, Chinese, Nagas, as well as those Rawangs, Lisus, and others who do not self-identify as Kachin. Many of these communities have little reason to support greater autonomy or independence for an ethnically defined Kachin State that combines and equates the interests of Wunpawng Mungdan specifically with Wunpawng myusha (Kachin people/'Kachin nation'). That the mainstream Kachin political discourse about Wunpawng Mungdan tends to mono-ethnicise the landscape has been disapprovingly noticed by some ethnically non-Kachin residents of the Kachin State whom I have interviewed. Kachin nationalists have countered in conversations with me that, 'the KIO represents all people of Kachin State, not only Kachins', but have then quickly admitted that even if that were true, its public pronouncements do not readily or typically communicate it as so. In Kachin public life and in popular imaginaries about the land's future, this potentially most consequential tension remains poorly discussed

10. W. van Schendel, 'Geographies of Knowing, Geographies of Ignorance: Jumping Scale in Southeast Asia', Environment and Planning D: Society and Space 20, no. 6 (2002). 
beyond a popular will to deport post-ceasefire Burman immigrants. We will explore this issue further below. ${ }^{11}$

The second concept employed in popular analysis, that of 'our Kachin people' or 'anhte Wunpawng myusha', is similarly crucial yet contested. Leadership within anhte Wunpawng Mungdan is not felt to reside ultimately with the KIO, which has experienced differing levels of popular support throughout its history, as discussed in many chapters in this book. Instead, Kachin nationalists deem social and political authority to reside in and arise from 'anhte (Jinghpaw) Wunpawng myusha' - 'Our Kachin nation/people.' Wunpawng' is a Jinghpaw language translation of the exonym 'Kachin', which emerged as a political ethnonym in the early $20^{\text {th }}$ century, was later promoted by the KIO, and is now ubiquitous. ${ }^{12}$ It functions mostly to emphasise how the Wunpawng nation unites several ethnic groups. This multi-group social structure has gradually emerged since the late $18^{\text {th }}$ century, when regional Jinghpaw elites intensified the process of socially and ritually integrating several ethnic populations in the Burma-China borderlands, sometimes by subjugation but not exclusively so. ${ }^{13}$

Today, Kachin nationalists of various deeply socio-culturally integrated 'sub-ethnicities' assert that their nation consists of six or seven equal 'Tribes.' ${ }^{14}$ The ethno-linguistic autonyms for these diverse groups

11. The external tensions produced by simplistically equating Wunpawng Mungdan with Wunpawng myusha and allowing this to dominate in discussions of the political future of the Kachin State became most apparent in recent years in activities promoted by the Ethnic Nationalities Council (ENC; see references to this in the chapters by Martin Smith and Mahkaw Hkun Sa, this volume). A series of State Constitution Drafting Committees were set up, including one for the Kachin State that was to deliberate upon the kind of constitution that an autonomous Kachin State might have within a federal Myanmar (see Mahkaw Hkun Sa, this volume). The attempt to bridge gaps with some non-Kachin populations by reassuring them that a political structure would be put in place that would guarantee the interests of non-Kachin populations in the State highlighted the need for long-term trust building around these issues. (Mandy Sadan, pers. comm.).

12. Sadan, Being and Becoming Kachin: Histories Beyond the State in the Borderworlds of Burma, 250, 339.

13. Ibid. 140-197.

14. See Mandy Sadan, 'Decolonizing Kachin: Ethnic Diversity and the Making of an Ethnic Category', in Exploring Ethnic Diversity in Burma, ed. M. Gravers (Copenhagen: NIAS Press, 2007); also François Robinne and Mandy Sadan, ed., 
are Jinghpaw, Lhaovo (Lawngwaw), Zaiwa, Lachid (Lachik), Rawang, Lisu, and Nung (increasingly, Nung Lungmi; see the chapter by Helen Mears for further discussion). Relying upon re-interpreted origin and ancient migration narratives, the Wunpawng nationalist theory argues that common ancestry and a cultural core unifies these historically different ethnic groups. Many Rawang and Lisu people, however, do not generally, or even at all, identify easily with the Jinghpaw-centred term '(Jinghpaw) Wunpawng'. Some Lhaovo and Lachid people, too, have dis-identified themselves from Wunpawng and the related political and social infrastructures of the KIO and the Kachin Baptist Convention (KBC) which promote this terminology. Similar internal fragmentations characterise also the Karen, Chin, and other major multi-ethnic nations in Myanmar, which often have relatively shorter histories of multi-group integration than do the Kachin groups. As in those instances, so too in the Kachin case, one should not read these contestations as somehow de-legitimising any sense of genuine shared nationhood or common political understandings of these relationships; many people strongly identify with these notions and through them bond as an inter-related anhte Wunpawng myusha.

Many Kachin nationalists perceive the ongoing contestations over the boundaries of Wunpawng myusha and over ethnic Jinghpaw political and cultural domination as a sensitive issue, best left unspoken and sometimes aggressively denied. They fear that opening up the issue can provide entryways for the Myanmar government's anti-KIO divide-andrule tactics, and indeed, it has already done so. Many objected to the national census of 2014, for example, arguing it was an opportunity for the Myanmar government to pursue its agenda of breaking apart and fatally undermining the social base of the ethno-political unity of the Kachin movement by recognising Kachin sub-groups independently from the census category 'Kachin', as mentioned later in this volume, too, by Mahkaw Hkun Sa. This tension therefore fed into a perception of threat, vulnerability, and national emergency. Helen Mears will later

Social Dynamics in the Highlands of Southeast Asia: Reconsidering Political Systems of Highland Burma by E. R. Leach (Leiden Brill, 2007). For an early critique of the tendency in academic literature to under-represent Kachin cultural heterogeneity see Chapter 2 in Ho Ts'ui-p'ing, 'Exchange, Person and Hierarchy: Rethinking the Kachin' (Unpublished PhD Dissertation, University of Virginia, 1997). 
discuss how material culture, too, has been influenced by some of this debate during the ceasefire period. ${ }^{15}$

The third major term of currently dominant Kachin nationalist theory is 'Karai Kasang' or Christian 'God'. The role of Karai Kasang as an actor in Kachin society is contested between different denominations and theologies. Different denominations fragment the Kachin population along spiritual lines: the majority American Baptist, the minority Roman Catholic, the Fundamentalist Baptist, the Anglican, and a range of smaller independent and house churches have all proliferated at different times and in different communities. ${ }^{16}$ However, I will here outline only a recently increasingly popular and influential Kachin nationalist theorisation of Karai Kasang, arising primarily from one certain lineage among Kachin Baptist theologians. I do this to show how in the lived worlds of many Kachins, but especially Baptists, Karai Kasang is a fundamental actor in the history of war, ceasefires, and all social and political processes.

These Baptist theorisations posit Wunpawng Mungdan as a land promised to, historically given to, and still to be fully redeemed by anhte Wunpawng myusha. This model is derived from what its theologians call 'the contextualisation' of the Old Testament. 'Contextualising' can mean reading the battles and travails of the ancient Israelites, their exodus from Ancient Egypt, and the eventual emergence of God's promised homeland, as lessons for peoples in the contemporary world, which can be used to frame an analysis of their own situation. In this local Kachin context, therefore, the 'Burmans' are recast as Ancient Egyptians and

15. For the foreseeable future, these ethnic differences, divisions, and inequalities remain a consequential tension in Kachin public life. However, in Kachin society today there is more political value in centring non-Jinghpaw groups within the Wunpawng construct more explicitly. This has been one of the effects of the opening up of space for critical discussion during the ceasefire period. Nonetheless, according to my research, the issues remain publicly little discussed inside Wunpawng-identifying society, as people choose to concentrate on the shared sense of threat from the Myanmar regime. The sensitivity itself connects strongly with Reshmi Banerjee's discussion in this volume of the causes and effects of territorial ethno-nationalism in north-east India.

16. Some of the tensions in religious affiliation mirror those described in the fragmentation of ethnic groups collectively referred to as 'Kachin'. This partly reflects the historical foundation of mission stations in specific locales and evangelical pathways arising from them over time. (Mandy Sadan, pers. comm.). 
anhte Wunpawng myusha as the enslaved Israelite tribes, who appeal to Karai Kasang to release them from bondage. In this view, Karai Kasang is deemed to pay attention to and have a particular purpose for oppressed nations, as evidenced by the examples taken from the Old Testament. To describe this, one younger-generation Kachin theologian has used the phrase 'God is God of nations. ${ }^{17}$

Individuals who believe that anhte Wunpawng myusha is a nation chosen by Karai Kasang, now on a path of temporary suffering toward the glory of a 'promised land', have found personal confirmation of this view in various ways. A commonly cited proof is the popular historiography whereby during the British colonial era 'He' resurrected the nation through religious conversion from 'near extinction' as a result of a supposed syphilis epidemic ${ }^{18}$ and Animist 'vice and barbarity.' 'God revived us' is what many Kachins have told me. Some Baptist pastors and other believers I have talked to see evidence of divine blessing in the abundance of natural resources in the Karai Kasang-given Wunpawng Mungdan. Others point to the homeland's 'unique position' between the world's two most populous countries, China and India; and so on.

This religious-nationalist model developed strongly during the last few decades of armed conflict in the Kachin Theological College near Myitkyina. ${ }^{19}$ I have found that certain socially influential Baptist theologians at the college drew their analytical frameworks from an array of theological traditions to develop an ethno-politicised 'Kachin theology'. Its sources include specifically Southeast Asian lineages of 'contextual theology', North East Indian 'tribal theology', Latin American-born 'liberation theology', neo-Animist re-interpretations of Jinghpaw native

17. Lagai Zau Nan, 'Globalization: A Kachin Ethnic Christian Response', RAYS: MIT [Myanmar Institute of Theology] Journal of Theology 8 (2007).

18. Mandy Sadan, 'Syphilis and the Kachin Regeneration Campaign, 1937-38', Journal of Burma Studies 14 (2010).

19. The college was founded in 1966, when the US Baptist mission-founded Bible School in Kutkai in northern Shan State relocated following the expulsion of foreign missionaries and a rapidly deteriorating political situation in that region. The college subsequently expanded its educational and training curriculum in the mid-1970s, when the conflict with the Burmese regime was particularly entrenched. It went on to become a centre of Kachin politico-cultural resistance and key provider of autonomous higher education programmes for ethnic Kachin youth. 
religion, as well as the globally common theological 'acculturation' practices of Baptist missionary evangelism, which Myanmar Baptists inherited from colonial-era US missionaries. ${ }^{20}$ This parallels developments in some Christian Karen, Naga, Chin, and other Christian theologies in Myanmar, and north-east India, and globally.

The current surge in the popularity of such nationalist theology also causes tensions: neither every Kachin person nor every KBC theologian subscribes to the positions outlined. Indeed, I have met considerable variety in the individual views of $\mathrm{KBC}$ pastors and other church leaders. Some unconvinced Kachins from the $\mathrm{KBC}$ and other denominations strongly oppose these particular interpretations, viewing them as theologically false or full of politically-oriented deceptions. Moreover, some Catholic Kachins have in conversations with me assertively criticised the Baptist majority and its nationalist theologies for 'falsely politicising religion'. Kachin Catholics are generally less likely to ethno-politicise their religion, primarily because, unlike the $\mathrm{KBC}$, Burma's Catholic Church has a multi-ethno-national congregation and leadership. There is moreover a tiny but growing circle of young foreign-educated Kachin intellectuals who dislike religion's influence in their society, condemn the popular political theologies, and rather support secularisation. Yet, the Baptist ethno-political theology has in the current war years been increasingly operating in tandem with KIO propaganda, familiarising Kachins from various denominations beyond the $\mathrm{KBC}$ with these beliefs, too.

Another central theological foundation of the $\mathrm{KBC}$ and its college, which ethno-politicises these ideas institutionally, is the 'holistic mission'. Kachin Baptists received this idea from early missionaries and it calls for one's prayer being accompanied by action. 'Action' here usually means community development projects, fighting against poverty, and working for social justice for ethnic Kachin society. Thus, even when Baptist Kachins have talked to me about Karai Kasang's perceived support for the cause of anhte Wunpawng myusha, they have often simultaneously expressed the principle of their 'holistic mission' by concluding, 'God helps those who help themselves'. Throughout the decades of military conflict, the KBC acted relatively autonomously, sending out

20. On missionary strategies of acculturation, see Sadan, Being and Becoming Kachin: Histories Beyond the State in the Borderworlds of Burma, 392, 97-8. 
young graduates from the college to fulfil its 'holistic mission'. However, Sadan has argued that the prevailing militarised conditions meant that it also had to act in cooperation with the KIO, resulting in an ever closer entangling of religion and nationalism in society as a whole. ${ }^{21}$ In the last few years, I have certainly observed significant cooperation and political overlap between the KBC and the KIO. Despite the powerful KBC's currently major role in keeping up public support for the KIO, the KIO itself remains a nationalist organisation not founded on religion or church denomination. These two institutions are now major pillars of Wunpawng national politics and social authority.

In conclusion, while these three conceptions of land, people and divinity, therefore, contain within them tensions that complicate everyday Kachin politics, in my ethnographic research I have found that these dominant strands of nationalist theory are finding increasing currency and recognition in Kachin society. This has been particularly marked since the collapse of the ceasefire in 2011. Support for the KIO undoubtedly waned during the mid-ceasefire era, as has been noted elsewhere in this book, especially by Kevin Woods and the chapters by Hkanhpa Tu Sadan and Mahkaw Hkun Sa. This was largely due to perceptions that its business orientation overshadowed political aspirations. Also, the assimilation or integration of Kachin youths into Myanmar and Burman society increased. Finally, different individuals and social groups subscribe to the dominant nationalist theory to varying degrees. Nonetheless, the ambitious ethno-political discourses and loyalties outlined here spread more widely across Kachin society as the experience of the ceasefire came to be understood along increasingly negative lines. We can surmise that the 1994 ceasefire helped to consolidate the making of Kachin patriotic ethno-national subjects within the theoretical framework outlined above, and that this process intensified in the years leading up to the collapse of the ceasefire in 2011, and after.

A very important reason why Kachin political identity has strengthened, as noted by many authors in this volume, is the sense of threat and suffering derived from experiences of the ongoing destructive and marginalising resource extraction and trading practices. These issues became heightened during the ceasefire era and came to be analysed in Kachin society through the evolving nationalist theoretical framework

21. Ibid. 380 . 
outlined above. This kind of analysis became central, and it helps to explain why a great portion of Kachin society rejected an easy return to ceasefire with the Myanmar Army. Thus, we will now proceed by briefly summarising the ceasefire era resource grabs followed by an analysis of Kachin popular understandings of those specific processes and their contemporary social and political outcomes.

\section{Ceasefire era resource grabs, suffering, activism}

After the 1994 ceasefire, the Kachin region's various military-political authorities opened up the formerly embattled but resource-rich subtropical landscape to the resource extraction companies from neighbouring China, as discussed in all the chapters of this volume in previous sections. Two decades of rapid expansion and the industrialisation of a variety of resource extraction fields followed. This included clear-cut logging of old-growth rainforests; industrial scale mining of the world's only commercial jadeite mines in Hpakant, and of gold and other minerals; the now famously suspended Myitsone mega-dam project; mono-crop plantations of various cash crops; the Shwe gas pipeline (in northern Shan State); as well as organised trades in the body parts of tigers, elephants, bears and other endangered wildlife.

That these numerous resource extraction projects were and continue to be predominantly monopolised by non-native corporations with military backing invokes for many Kachin people a bitter sense of injustice, as it does for other peoples in Myanmar, such as the Ta'ang people as described by Patrick Meehan in his chapter in this volume. The situation contrasts with the widespread belief in Kachin society that there is a right and proper collective national entitlement held by anhte Wunpawng myusha to manage the rich natural resources of Wunpawng Mungdan. The sense of Kachin ownership gathers strength from the broader popular theoretical framework discussed above, which assumes that rights over anhte Wunpawng Mungdan have been mandated specifically for the welfare of the Wunpawng myusha through histories that were political-economic-cultural or cosmological-divine, or both.

The most bemoaned example of these many perceived deep injustices is the KIO's post-ceasefire loss of the Hpakant jadeite mines, resulting in an aggressive non-Kachin takeover of most of the business from the mines. Hpakant Township is the world's only source of types of jadeite 
that Han-Chinese societies have long adored and which make for an annual multi-billion dollar licit and illicit trade. ${ }^{22}$ Many Kachin people envision that all such resources and profits could and indeed should be used to ensure the welfare and national future of the Wunpawng myusha, including the building of a self-determined homeland. In 2010 in Ruili, one well-respected Kachin jade trader told me:

I almost burst into crying when I first went to Guangzhou - enormous amounts of jade coming from our country, no ... our area. The owners - all Chinese. Out of 10,000 shops I couldn't find one-two Kachins. This makes me very sad, because this is not helping our people. We could sustain our nation with jade, even without [KIO's] forestry.

Inevitably, people in the Kachin-China border areas are those most painfully aware of this border's sharply uneven economic geography. The Chinese border marks the beginning of 'a different world', where the spectre of cross-border comparisons looms large. Busy construction sites are seen, fed by smooth roads and other infrastructure; shops with plentiful amounts of food and medicine, convenience stores, ATMs, cheap cell phone connections seem to be abundant; and all this is backed up by a sense of the global might of the Chinese political and economic system. ${ }^{23}$ Reflecting on such landscapes, an erudite KIO senior cultural leader in Laiza laughed sadly before saying:

When KIO started, Ruili, Yingjiang on the Chinese side were very poor villages. Now, they are more developed towns than Rangoon or

22. Global Witness, 'Jade: Myanmar's Big State Secret' (2015).

23. On China's Jingpo perspectives upon the other side of the Kachin border, see the chapter byHo Ts'ui P'ing in this volume. On the political-geographic dynamics of the $\mathrm{KIO}-\mathrm{China}$ border and cross-border Jingpo/Kachin interactions, see Karin Dean, 'Mapping the Kachin Political Landscape: Constructing, Contesting and Crossing Borders', in Exploring Ethnic Diversity in Burma, ed. Mikael Gravers (Copenhagen: NIAS Press, 2007); Karin Dean, 'Spaces and territorialities on the Sino-Burmese boundary: China, Burma and the Kachin', Political Geography 24, no. 7 (2005); and Karin Dean, 'Spaces, Territorialities and Ethnography on the Thai-, Sino- and Indo-Myanmar Boundaries', (2011). On post-ceasefire economic development in KIO border towns, see Lanau Roi Aung, 'Kachin Borderlanders: A Case Study of Laiza Town Along the Yunnan-Myanmar Frontier Area' (Unpublished MA thesis, Chiang Mai University, Thailand, 2009); Roi Nu, 'Land Use Pattern Changes after Economic Integration in Mai Ja Yang Village, Kachin State, Myanmar' (Unpublished MA thesis, Khon Kaen University, Thailand, 2009). 
Mandalay, ha-ha! But yes, this makes us very sad, because the profit is in the hands of other people. The Kachin hand is empty. Just like all our valuable trees, the big money reaches only the Chinese side. The development and prosperity is possible only on the Chinese side.

Even more frustratingly for Wunpawng patriots, much human suffering resulted from the ceasefire era expansion of resource extraction along these lines. The projects commonly involved dispossessing villagers forcefully of their lands. They also left ecological degradation unchecked. As a result, the effects of these extractive practices have often been devastating for the area's impoverished people. They have seen villages displaced and people killed in preventable accidents. People, rivers and river life have been poisoned by toxic waste from gold mining. Swathes of farmland have been confiscated for mono-crop plantations. Most notoriously, the dramatic increase in chronic and ultimately lethal drug addictions and infection with HIV/AIDS has plagued Hpakant's mining population and the rest of the region's society. The violence, injustice, and suffering brought to many people's lives in the region have been documented by local and transnational NGOs, such as the Kachin Development Networking Group and Global Witness.

Altogether, Chinese, Burmese, and Kachin economic elites and militarily backed corporations have profited massively, while native land-owning villagers, extractive labourers, and small-scale traders of various ethnicities have benefited comparatively little. We should not understate how the post-1994 economic developments did help the livelihoods and very survival of impoverished people in the Kachin region. Moreover, the relative peace of the ceasefire era saved countless human lives. Yet, from both a local and an outside perspective, it might only be fair and accurate to conclude that large-scale resource grabs took place and that those who enriched themselves have often systematically destroyed human and other lives.

These and other developments in the region triggered a response in a new post-ceasefire Kachin activism, which grew incrementally after 1994 as the Myanmar government's relative easing of restrictions on social activity allowed for the development of local NGOs and other forms of social-political activity. ${ }^{24}$ Much of the initial post-ceasefire

24. Tom Kramer, Civil Society Gaining Ground: Opportunities for Change and Development in Burma (Amsterdam: Transnational Institute, 2011). On the impact of Kachin 
social activism was sheltered within the $\mathrm{KBC}$ and its 'holistic mission', although soon transnational connections and ideologies, especially in the Myanmar exile bases of Chiang Mai, became increasingly important, as described later by Mahkaw Hkun Sa. I cannot detail the landscape of all these new Kachin social activities and of the emergence of a Kachin environmentalist ideology here. However, I do want to emphasise the socially leading roles of these actors - social and environmental activists, educators, church leaders, several NGOs, and some businesspeople, all often mutually overlapping - in the collective work of making sense of the ethnic nation's social and ecological predicament. We should now turn, therefore, to exploring some of the popular analysis of the implications of these developments in more detail.

\section{Popular analysis and 'Burman conspiracy'}

Kachin society in the years after the 1994 ceasefire continuously accumulated individual experiences of how foreign-led industrialised resource extraction dispossessed fellow Kachins and made people suffer. This accumulation became a major impetus for Kachin individuals and groups to disseminate their analysis of what was going on in the Karai Kasang-given Wunpawng Mungdan, and how it was affecting anhte Wunpawng myusha. These analyses have since been honed, transmitted, and popularised via a variety of media. These include, for example, Sunday service Bible sermons and political karaoke music videos; exilebased online media and 'community development' youth camps; activist meetings with farmers in quiet rice field huts and people's conversations at social gatherings with extended kin. ${ }^{25}$

The popularised analyses of the processes of resource grab in the Kachin ceasefire era are mostly exercises in generalisation and deduction. Both activists and other Kachin people collect knowledge, spread information, and react to the many individual experiences and accounts

diaspora political activism in the U.K. and beyond, see Mahkaw Hkun Sa in this volume.

25. For a discussion of Kachin social mobilising through online networks during the current war, see Karin Dean, 'The Spatiality and Borderless-Ness of Contentious Politics: Kachin Mobilities as Capability', in Myanmar's Mountain and Maritime Borderscapes: Local Practices, Boundary-Making and Figured Worlds, ed. Su-Ann Oh (Singapore: ISEAS Press, 2016). See also Mahkaw Hkun Sa, this volume. 
of injustice, harm, and perceived danger from non-Wunpawng 'foreign' business expansion. What emerges are perceived patterns of land and resource dispossession by military force, ecological deterioration, violence, accelerating Burman in-migration, and specifically Kachin human suffering. These patterns are then generalised onto an ethno-national landscape: they are understood as a national issue and, ultimately, as an existential threat. In terms of general conclusions, many Kachin people situate such an analysis directly into the broad context of a native history of ethno-military conflict and 'cunning betrayals' by 'the Burmans'. Doing so, they both contribute to and rely upon an already popular conspiratorial analysis of why - for decades - Kachin people have experienced various forms of abuse, conflict, and marginalisation. For them, the perceived complex of existential threats indicates that a deliberate assault on anhte Wunpawng myusha as a whole was manifest in the post-1994 ceasefire period.

Field research I conducted from 2010-14 indicates that such beliefs have been socially and geographically widespread within Kachin society during this period. This time obviously coincides with the last contentious years of the 1994-2011 ceasefire and those immediately following its breakdown. It was a time when Kachin resistance to a new ceasefire seemed to frustrate not only the Burmese government but also many foreign observers, investors and policy makers who found it inconvenient'. Understanding the perception of threats and vulnerabilities outlined here may go some way to explaining what seemed to many outside observers to be an 'irrational' and self-destructive political stance. These perceptions were and are still expressed by various ethno-national elites, by politically engaged young people from far-flung, infrastructure-poor villages, as well as by those from towns at the hub of modern Kachin social and political life. This was evident at an ethnic Kachin church youth training held near Myitkyina in 2011, a month after the war had restarted, to which participants came from across the Kachin region. A group of young men brought up the idea that the social and ecological devastation that they experienced personally or had heard about might be intended as a form of 'ethnic cleansing'. One young man discussed this fear in the following way:

When business comes to our land, they get permits from the government without even knowing where are located Hpakant, Waingmaw, and so on. 
They don't even know where this land is, but they already have the permit to destroy that land. Is this ethnic cleansing from behalf of the government? We don't know, still more research needs to be done ...

Another trainee picked up this idea, asking: 'What is really behind the [Myitsone] Dam? Are they trying to finish off the Kachin people? Or is it just business?' Namely, some people came to suspect that the Myitsone hydroelectric mega-project might help 'finish off' the already embattled Kachin nation, since Kachin activists calculated that the dam's gigantic reservoir would displace tens of thousands of villagers. The reservoir would also tear a hole in the middle of the 'heartland' of anhte Wunpawng Mungdan. Finally yet importantly, these activists claim that the dam is being built in an earthquake-prone area, which resonates with some of the discourses around similar dam projects in north-east India according to Reshmi Banerjee's account in this book. According to them, any flooding from it if it became damaged would kill the downstream population of Myitkyina. ${ }^{26}$

At the youth training, a fervent discussion ensued, with young people sharing their anxieties over how the foreign-led mining, logging, plantations and damming will affect the future of the Wunpawng myusha. Almost everyone had a story to tell, typically about the regular, day-to-day misfortunes of local people seen through this wider lens of national-existential threat. No one questioned that the regime is out to destroy the Kachin people: the only question was how much the resource development projects and resulting destruction of land may be part of the plan. Indeed, popular analysis in Kachin and some other nonBurman societies in Myanmar, as noted also by Gravers and Meehan in this volume, maintains that the regime's resource extraction concessions are primarily a hostile military-political strategy.

Some native and outside analysts argue the same about a broader variety of land-related projects beyond resource extraction. For instance, some view not only the logging, mining, and dam concessions as anti-KIO and anti-Wunpawng activities, but also the Hukawng Valley's controversial tiger reserve and the plans to upgrade the Ledo Road as

26. For an extended discussion of the dam conflict, see Laur Kiik, 'Nationalism and anti-ethno-politics: why "Chinese Development" failed at Myanmar's Myitsone Dam', Eurasian Geography and Economics, June 22 (2016). 
part of an India-to-China highway. ${ }^{27}$ A Baptist leader I talked to analysed that potential highway as a covert strategy to uproot the KIA and other 'patriotic armies' in Myanmar:

One way how the military government behaves in these kinds of situations is to say that developing transportation is the most important for development. And then strategically they build roads through the territories of patriotic armies, even when it is not necessary to build over there. In reality, the goal is not development. The Hukawng Valley is our main place. Very important. There the KIA began. Like the Karens have the Three Pagodas area - which the ASEAN road is also planned through. In the Hukawng area that they want to build a highway through is the 5th Brigade of the KIA. What is the point? They are trying strategically to weaken the ethnic groups. Obviously, they are trying to dominate the minorities economically, politically, and militarily.

As the previous quote exemplifies well, a central aspect of this perceived military-political strategy is territorial. Namely, by designating large areas of land as resource concessions to outside companies and by having those actors establish a militarily-backed presence, the government may be able to decrease the KIO's and general ethnic Kachin influence in contested areas. The process establishes state-governmental authority, restricts access to resources by the KIO and civilians, and thus gradually squeezes out military opposition and ethnic Wunpawng control. ${ }^{28}$

For the sake of accuracy and completeness, though, arguments that some Myanmar natural resource concessions are a state-military strategy against a minority ethno-national army must be set in a critical context. True, in academic literature, there are affirming case studies. Raymond L. Bryant was first to develop this argument in the context of logging concessions by the Ne Win and SLORC regimes and Karen

27. Such analyses of the Hukawng tiger reserve are also found in Vanessa Lamb, 'Between Tigers and Triggers: Conservation and Conflict in Burma's Hugawng Valley', Watershed 12, no. 2 (2007); Z. Noam, 'Eco-Authoritarian Conservation and Ethnic Conflict in Burma', Policy Matters: Conservation and Human Rights 15 (2007). For some related critical comments, see my discussion briefly below.

28. Indeed, extractive projects with Chinese participation put the $\mathrm{KIO}$ in a particularly difficult situation because the organisation has traditionally needed good relations with the Chinese authorities in Yunnan to sustain its border strongholds (also see the chapters by Lee Jones, Enze Han, and Ho Ts'ui-p'ing in this volume). 
armed resistance. ${ }^{29}$ Kevin Woods' 'development-as-counterinsurgency' in northern Myanmar thesis (discussed in his chapter in this volume) may be viewed as a de-ethnopoliticised translation of some popular native analyses into the critical-theoretical registers of social science. ${ }^{30}$ However, in my personal view, there are also analytically problematic aspects. While the popular analyses themselves stem from decades of collective experiences and intimate observations, they do pre-suppose a high level of integration, coherence, and stability within governmentalmilitary planning and policy that may be unlikely to exist. Ardeth Maung Thawnghmung has for similar reasons called into question 'the widely held image of the military regime in Burma as a unitary actor $[\ldots],{ }^{31}$ Moreover, the analysis tends to ignore a variety of alternative motivations for the military-state-associated actors. Regime officials might be more concerned with making money for personal profit, for supplying their troops, or for the military-state's budget, instead of counterinsurgency or annihilation of an ethnic nation. Similarly, such analyses tend to leave out the broader context of freewheeling crony-capitalism, of Myanmar Army territorial expansion without practical need for legitimising cover projects, and of ill-designed mega-development agendas across all of Myanmar. Finally, setting important limits to any schemes of territorial takeover would be the fact that throughout the ceasefire period the KIO never tolerated serious breaches across the delineated administrative borders of its autonomous quasi-state. ${ }^{32}$ Thus, while we should take these analyses seriously as insights into the very real worlds that people

29. Raymond L. Bryant, The Political Ecology of Forestry in Burma, 1824-1994 (London: Hurst, 1997).

30. See Kevin Woods, in this volume; and Kevin Woods, 'Ceasefire Capitalism: Military-Private Partnerships, Resource Concessions and Military State Building in the Burma-China Borderlands', Journal of Peasant Studies 38, no. 4 (2011).

31. Ardeth Maung Thawnghmung, Behind the Teak Curtain: Authoritarianism, Agricultural Policies and Political Legitimacy in Rural Burma (London: Kegan Paul International, 2003), 1.

32. Karin Dean, 'Struggle over Space in Myanmar: Military State Building and the Kachin Ceasefire', in Autonomy and Armed Separatism: Case Studies from South and Southeast Asia, ed. Michelle Ann Miller (Singapore: Institute of Southeast Asian Studies (ISEAS) Press, 2012). 
live within, we should simultaneously retain a healthily cautious perspective in how we represent and understand their significance. ${ }^{33}$

It may be hard to figure out the complex realities, but a good deal of Kachin popular analysis argues that behind the region's booming resource economy there are territorial processes encouraged by the Myanmar government on an even broader scale. Again, this analysis is embedded in the nationalist theory discussed above, which posits a direct connection between the interests of Wunpawng Mungdan and anhte Wunpawng myusha - between the 'land of Kachins' and Kachin people. Kachin social leaders fear that 'outsiders' are gradually removing anhte Wunpawng Mungdan itself from their nation's hands. They point to foreign ownership of the very soil of the contested homeland in the form of mono-crop plantations. They also point to non-Kachin economic domination, which Kachin people experience most visibly in day-to-day life in their encounters with non-Kachin street vendors and shop owners in places like Myitkyina. Many Kachin people suspect that a process by which land is passing into non-Wunpawng hands may be part of a long-term plan to remove all Wunpawng control over their resource-rich homeland. A Kachin student pressed this idea onto me in summer 2011 in Yangon, where local Kachins were at the time terrified by intensified levels of state surveillance over them since the war with the KIA had just begun. As we sipped beer in an outdoor restaurant, we discussed with hushed voices the Kachin predicament:

Burma now started fighting with the KIA, in order to give Kachinland away to China. Because there are so many natural resources.

33. Certainly, one Myanmar regime strategy against the KIO/KIA that many local and outside analysts affirm particularly uniformly is divide-and-rule. This strategy targets both the internal unity of the KIO/KIA and its relationships with other armed groups. According to such analysis, military-government authorities have used resource concessions to undermine Myanmar's ethnic military organisations by tying them to the formal state-controlled economy (see also the chapter by Patrick Meehan in this volume). This corrupts their leadership and creates business-related dissent and divisions amid their ranks. The regime has also treated the leaders of KIO splinter groups and anti-KIO militias, such as the Lasang Awng Wa Peace Group and Tanggu Dang's ethnic Rawang Rebellion Resistance Force, favourably, enabling them to have lucrative logging and mining concession rights and allotting them territory and military protection. Other chapters in this volume consider in more detail the various tensions that have emerged inside the KIO during the ceasefire period, and so this will not be expanded upon in this chapter. 
I am stunned by the proposition: 'Give all Kachinland to China...?' I wonder from where such analysis reaches young Kachin people. Suspecting the media interventions of exiled activist networks might be promoting this unlikely form of analysis, I asked: 'Where did you read this?'

I don't think so because of reading something, but because of seeing by myself. When I worked in a gold mine, the owners were Chinese. When I worked in the plantations near Laiza, the owners were Chinese. The Chinese own land territories larger than Myitkyina town as plantations. And in the heart of Myitkyina, all the best shops are Chinese. Even on the town market-place, the best shops are Chinese. So I want to learn the Chinese language. For business purposes ...

As this kind of non-native domination expanded in the region's resource-grab-based economy after the 1994 ceasefire, the Wunpawng nationalists came to face one of their deepest reasons for analysing the evolving situation as a national emergency: the speeding up of in-migration from lowland Myanmar. Reports have spread widely that the government is founding new villages in Kachin State, bringing in ethnic Burman residents. Some Kachin people told me that they heard the government has a yearly plan of sending in huge numbers of Burman migrants. One nationalist cited meeting a few Burman youths with one-way tickets on the train to Myitkyina; for her, everyday little incidents like this provide the evidence that the broader social world of Wunpawng nationality is extremely vulnerable to a 'Burman conspiracy'. However, the single most notorious example of this alleged physical Burmanisation project via resource extraction concessions is the Yuzana Company's vast mono-crop plantations on violently confiscated land in Hukawng Valley. The sense of a national emergency was expressed by the Kachin News Group when it reported in unverifiable terms that 'the SPDC plans to settle up to 200,000 Bamar [Burman] people in the Hukawng Valley, ostensibly to work on the Yuzana plantations' (emphasis added). ${ }^{34}$

Thus, observing the gradual population changes in one's surrounding society and hearing reports of plans for more massive in-migration, many Kachins assert that the Myanmar government is deliberately orchestrating population movement in order to marginalise ethnic

34. KNG (Kachin News Group), 'Junta to Resettle 200,000 Burmans in Hukawng Valley', (7 March 2009). 
Kachin people demographically. The suspected goal is to Burmanise anhte Wunpawng Mungdan and then to take over the land for the last time. This analysis probably underestimates the independent incentive for lowland Myanmar's many impoverished people to move to regions like Kachin State to try to find their fortune in the resource economy, whether it be as one of tens of thousands of Burman, Arakanese, and other miners in Hpakant, as a plantation labourer, or as a hydraulic gold digger. However, people's observations and popularised analyses reflect some very real social worlds.

Indeed, continuous and rapid in-migration will likely soon minoritise the Wunpawng myusha demographically within the already deeply multi-ethnic population of Kachin State. This minoritisation may have already occurred. Most immediately relevant in 2015, this change will likely have irreversible consequences for future election results. In the long term, as the more politically minded Kachins realise in fear, it will eventually make almost impossible all Kachin pursuits for securing independence or general ethno-national control over the State. The demographic grounds for claiming land and political autonomy, as well as for sustaining these at a practical level, will have significantly diminished. More than anything else, this quietly occurring change can constitute a historical point of no return for the beleaguered Wunpawng patriots.

Thus, the population size of anhte Wunpawng myusha itself, which despite the recent census is unknown and sometimes exaggerated by nationalists, has become a terrifying issue for some. An elderly environmentalist confided to me, in his otherwise calm voice but with a distinctly painful note rising: 'Actually, our population is now only below a million. Although the $\mathrm{KBC}$ will get angry if I say so, they will not agree. They even say that KBC has 300,000 members. But it doesn't'. For the nation to persevere, some Kachin elders have called upon people to have more children.

Facing this precarious situation, Kachin nationalists relate the changing demographic balances to the threat that the beloved Wunpawng Mungdan itself will be disassociated from Kachin people and 'lost' from the nation's hands. As noted earlier, the 2014 Myanmar population census triggered long-held fears that Wunpawng Mungdan would be 'taken' from Kachins through clever 'divide-and-rule' ethnic identification categories, which would show Kachin-identifying people as a minority. 
Some say former governments have added pieces of Kachin State to Sagaing Division, reducing Wunpawng Mungdan step-by-step from the map. Alternatively, take this analysis by a KBC leader:

We need a very fair Constitution. Without it, our nation can go extinct. Because many people are coming here. In the Constitution now it says that, if the majority of the State population agrees, a State's name can be changed. That means, if we aren't strong enough, we could lose the State - lose the Nation. Secondly, in the Constitution it says that the President has the right to define the Union's territory. He could undo our State. And even if those things weren't written there, in my opinion, in twenty years the State and nation might still disappear - because of assimilation.

As this leader's conclusion exemplifies, there is a painful awareness among Wunpawng nationalists that, besides in-migration, Kachin society is facing an on-going, gradual cultural and linguistic assimilation into Burman society. Many young people I know complain about their own limited Jinghpaw language vocabulary and tendency to switch to using Burmese. This results largely from the decades-long ban on nonBurmese mother-tongue education in state schools. Some patriotic analysts are alarmed at evidence of the influence of both a globalised modernity and of a Yangon-centred Myanmar modernity. Young men wear 'modern' pants instead of the standardised 'traditional Wunpawng' buhkrawng or skirt cloth. Young people listen to Burman music and there is a local fascination with South Korean soap operas, which some believe the government-owned television stations encourage to de-politicise the public mindset strategically. Kachins in Yangon and Mandalay are losing their ethno-national identity and language skills. Finally yet importantly, Kachin nationalists bemoan the government-supported Myanmar Buddhist Sangha expanding even to the furthest corners of Wunpawng Mungdan while they assert that authorities simultaneously restrict the building of new Kachin churches.

As is common in patriarchal nationalisms, of which contemporary Kachin ethno-nationalism is one, a particular site of populational and 'racial' vulnerability is believed to be the female body. This, too, is embroiled in popular understandings of a covert strategy to destroy the Kachin nation (see also Nhkum Bu Lu and Jenny Hedström, this volume). The many unpunished rapes committed by soldiers in the 
Myanmar Army, an increased hardening of attitudes towards inter-ethnic marriages beyond the Wunpawng myusha, and the trafficking of Kachin women to China have all been a part of this analysis. ${ }^{35}$ Wunpawng women's marriages to Burman men are believed to be encouraged by the military government in a secret strategy to Burmanise the population. As in Karen and other minority societies, alleged Myanmar Army documents are circulated as proof about a system of rewards given to Burman soldiers for marrying ethno-national minority women. ${ }^{36}$

Moreover, the vast majority of Kachin social elites, students, and activists that I talked to are convinced that the drug use epidemic among the Kachin population is being consciously organised and encouraged by military strategists of the regime aiming to destroy a new young generation of potential revolutionaries and to weaken the Kachin nation from within. One of their main claims is that the Myanmar police deliberately do not stop or arrest ethnic Kachin drug users. This perception is wide-spread, even though many non-Kachins in the region are equally addicted and unprosecuted; the drug market is flooded from large-scale production centres in the region; the deep corruption of the Myanmar police force could explain its lack of anti-drug action more directly; and Myanmar police have actually arrested and jailed at least some Kachin drug users. Thus, this popular analysis expresses, again, the broader overall theoretical assumption that the regime is conspiring against the Wunpawng nation specifically. Such broad assumptions stem from decades of personal experiences before, during, and after the ceasefire, when Myanmar Army and government representatives have with impunity subjected Kachin civilians to abuse, neglect, and routinely aggressive and disrespectful everyday encounters. The chapter by Hkanhpa Tu Sadan details some of the common experiences that affected people and undermined their sense of personal security.

35. On the trafficking of women, see KWAT (Kachin Women's Association Thailand), 'Driven Away: Trafficking of Kachin Women on the China-Burma Border' (2005); KWAT (Kachin Women's Association Thailand), 'Eastward Bound: An Update on Migration \& Trafficking of Kachin Women on the China-Burma Border' (2008); and KWAT (Kachin Women's Association Thailand), 'Pushed to the Brink: Conflict and Human Trafficking on the Kachin-China Border' (2013).

36. On women's experiences during the ceasefire years, see the chapter by Nhkum $\mathrm{Bu}$ $\mathrm{Lu}$ in this volume. 
In this broader experiential and analytical context, Kachin nationalists often view the Myanmar Army's post-2011 military campaign against the Kachin Independence Organisation, and the accompanying horrific abuses and crimes against civilians, as a war 'against the Kachin population as a whole. This is what KIO Chairman Lanyaw Zawng Hkra himself has claimed, for instance in an open letter to the UN SecretaryGeneral. ${ }^{37}$ Some Kachins say the war amounts to 'ethnic cleansing'. Perhaps Myanmar military-political elites may actually have little desire to annihilate, rather than subjugate, non-Burman populations for their political or economic goals. Nonetheless, after decades of experiencing the intensely violent, claustrophobic, and terrifying ethno-political everyday of Myanmar, many alternative explanations of what is going on may not seem all that 'obvious' to native ethno-national leaders, activists, and the broader population, or to sympathetic outside observers.

\section{For the land yet-to-be}

Taken together, all this popularised analysis reaches an overall conclusion about the realities of the ceasefire era. It amounts to this: anhte Wunpawng myusha (our Kachin nation) has overwhelming reasons to fear that, through a diverse complex of acute dangers and enemy plans, our nation will soon be subdued, be slowly exhausted, and will eventually 'go extinct'. Those Wunpawng nationalists who to a greater or lesser extent perceive an ongoing 'Burman conspiracy' sometimes call the ceasefire era reality the cold war or a 'genocide' by cunning means. The way these popular Kachin analyses generalise and deduce from social realities reflects how deeply all social life in Myanmar is ethnopoliticized and how often people suspect that any event, small or large, could be part of an ethnocidal regime conspiracy. The depth of these analyses, feelings, and social worlds are a fact to be taken seriously. That this should be the prevalent popular analysis of a period of 17 years of armed peace and relative economic development reflects the scale of the suffering, hostility, and threat experienced and perceived in Kachin society during that time. In much of contemporary Wunpawng society, the given analytical conclusion inspires a sense of emergency and a determination to resist. In 2011 in Myitkyina, shortly after the war had

37. KNG (Kachin News Group), 'May 15 KIO Chairman's Letter to UN General Secretary Ban Ki-Moon’ (17 May 2012). 
re-started, a young activist stunned me, as we sat in her little quarters joking and chatting, by suddenly uttering her tragic conviction: 'If we don't fight this time, we will all die'.

For many Kachin Baptists, this alarming conclusion is countered by a theory of and belief in eventual national victory on a longer, more cosmologically defined time-scale. This theory and belief is premised on the perceived definitive authority of the Bible, theorised nationalistically so that Karai Kasang's (God's) promise to the Christian Wunpawng myusha seems evident. For many, religious hope is the source of resolve and certainty in the correctness of Wunpawng struggles. For the KBC congregation in particular, the current ethno-national dangers and continuous human suffering are theorised as the difficult yet temporary journey to a 'Kachin Canaan'. 'Wunpawng Hkanan' is the title of a widely popular new song and $2013 \mathrm{KBC}$ music video DVD, which documents the suffering of Kachin villagers displaced by war. Believers pray for such a land to emerge one day, as 'God's plan' for the Kachin nation unfolds in perceived cosmological parallels to the Israelites of the Old Testament.

Much of Kachin society now lives daily in a world that combines national emergency, on the one hand, with collective hope and resistance on the other. In 2014, a 20-year-old Kachin youth told me, with his body trembling, 'Sometimes at nights, when I think about the situation of our Kachin people now, I am crying in my bed'. His anger and sorrow make him determined to contribute somehow to the national struggle of anhte Wunpawng myusha. He tells me he wants to become a leader in this time of national emergency. But Wunpawng historiography, collective experiences, popular analyses, and broader nationalist theory point him to entirely different directions than those of lowland Myanmar's civilians, democrats, military and state leaders who, agitatedly, perceive Kachin society as 'stubborn' or perhaps 'too emotional'.

The direction that individuals like him are committed to is the demand for 'liberation', as in Baptist theological discourses, or 'revolution' in line with the discourse of the KIO. Generally, the terms 'liberation' and 'revolution' are defined as ethno-national independence and restoration of ownership of the Karai Kasang-given Wunpawng Mungdan. Due to the popular analysis of the ceasefire era experience, the ongoing military aggressions, and the dominant historiography of 'multiple betrayals by the deceitful Burmans', many Kachin people now consider it 'hopeless 
to live together with' the Myanmar government and Burman people at a general level. As one KIA battalion leader put it in his speech, now instead, 'we are asking God directly' for self-determination. ${ }^{38}$ KIA soldiers pray before battle and, since recently, the $\mathrm{KBC}$ churches organise monthly prayer fasts asking for the KIA's victory and for national independence. Elderly Kachin women are reported to have prayed aloud in a church 'Please, God, do not let the KIA waste any of their bullets', meaning that each one should find its target in the body of a Tatmadaw. ${ }^{39}$

Moreover, there are and will be vast social consequences to the onthe-ground reality that tens of thousands of Kachin villagers have since the 2011 war lived tightly together in impoverished refugee camps in the $\mathrm{KIO}$ and government territories. Altogether making up a huge fraction of the whole Kachin population, they have shared among each other their common stories of displacement, dispossession, and trauma, easily theorisable as part of a uniting Wunpawng discourse and historiography of suffering. This communication and unprecedented inter-relating will likely produce a strengthened Wunpawng ethno-nationalism against an analytically generalised 'Burman Other' and vehemently for a future nation still-to-be-realised, as it has for Karen and other ethnic nationalisms in the decades-old refugee camps in Thailand..$^{40}$

Thus, while the KIO at the time of writing refuses a formal new ceasefire, as it works towards an ethno-nationally federalised Myanmar, there is a complex social world beyond, where many individuals are ultimately committed to building for anhte Wunpawng myusha collectively a land yet-to-be. Participants in this broad social project cultivate a strong sense of individual responsibility to contribute to the struggle, as one lives in these 'times of revolution'. In the approach of these people, much social, educational, artistic, political, military, diplomatic, environmental, and other work needs to be done now, not only to fight against the analysed threat of imminent national exhaustion, but also progressively to prepare ground for a nation-and-country yet-to-be. Some hope that federalist autonomy, which has since Chairman Maran Brang Seng's time been the official goal of the KIO, could merely be a temporary step

38. KNG (Kachin News Group), 'KIA Trains Arakanese Recruits' (2 October 2012).

39. Mandy Sadan, pers. comm.

40. Ananda Rajah, 'A "Nation of Intent” in Burma: Karen Ethno-Nationalism, Nationalism and Narrations of Nation', The Pacific Review 15, no. 4 (2002). 
towards eventual full independence in a pragmatic and 'more realistic' systematic strategy. The more independence-minded people envision various versions of an eventual Wunpawng Mungdan, where Burman people must apply for residence permits, public life and universities are run in the Jinghpaw language, business thrives at the juncture of great China and India, natural resources serve ethno-national development, and a successful Christian modernity inspires neighbouring countries.

Other self-identified Kachin patriots disagree. They also quietly work for an envisioned land still-to-be-built, but instead of independence support ethno-nationally structured federalism as an acceptable and 'still more realistic' solution. Sometimes these people worry about the horrors of a hopeless war with Burma. In 2015, for example, I listened to a group of critically minded youths condemn the Wunpawng myusha's elites for 'sending other people's kids to die in war'. Some feel that a fully independent Wunpawng Mungdan could not prosper, because it is landlocked and 'not educated enough yet'. Nonetheless, many of them, too, disapprove now of overly apolitical attempts to reintroduce a ceasefire. Altogether, amid the current battles, anger and humanitarian crisis, the question whether one wants anhte Wunpawng myusha to proceed in pursuit of full state independence or merely federal autonomy within Myanmar has become a sensitive, all-but-unvoiced debate inside Kachin society.

What matters in the context of this chapter, though, is that people's positions in this debate have much to do with the strength of their subscription to the particular analyses and nationalist cosmological theories explored above. These subscriptions correlate significantly with the complex religious and ethnic differences inside Kachin society. There are considerably diverse viewpoints and no uniform 'the Kachin perspective.' Today, the dominant theorisations of nation-and-land and the popular analyses of the ceasefire era as a time of national emergency direct large parts of Kachin society to commit to the collective nationalist project for a future homeland, rather than subscribe to a compromising ceasefire. In a way, these people are subjects of a land-yet-to-be.

What has complicated the signing of a new ceasefire from the Kachin publics' side is not only the collective ceasefire era experience in itself, but what sense people have made of it - in their personal and collective analyses, within their evolving theoretical frameworks. The argument in 
this chapter highlights the importance of understanding how notions of collective experiences during the ceasefire era have been formulated and how they influence present social responses to wider political developments. The chapter seeks to emphasise how crucial this decades-long development of popular analyses has been to the collective formulation and popularisation of generalised understandings about the past, present and future of 'Kachin land'. Both contemporary leaders and new generations of Kachin national subjects continue their analyses and actions from these grounds. The 'trust-building' so often called for in Myanmar and in other similar conflicts means engaging openly, practically, and critically not only with traumatic collective experiences (the 'emotional' thesis) and with formal political demands (the 'federalism' thesis), but also with the publics' deeply negative analyses of their social worlds and with uncomfortably other visions for the homeland yet-to-be. 